\title{
Parenthood and Parenting in Modern Russia
}

\author{
Zarethan Khadji-Murzaevna Saralieva ${ }^{1}$, Irina Eduardovna Petrova ${ }^{1} \&$ Nadezhda Yurievna Egorova ${ }^{1}$ \\ ${ }^{1}$ Lobachevsky State University of Nizhni Novgorod-National Research University, Nizhny Novgorod, Russia \\ Correspondence: Zarethan Khadji-Murzaevna Saralieva, Lobachevsky State University of Nizhni \\ Novgorod-National Research University, 603950, pr. Gagarina, 23, Nizhny Novgorod, Russia.
}

Received: July 30, 2014 Accepted: September 30, 2014 Online Published: December 30, 2014

doi:10.5539/ass.v11n3p255 URL: http://dx.doi.org/10.5539/ass.v11n3p255

\begin{abstract}
The second half of the 20th and the beginning of the 21 st centuries saw massive transformations in different domains of public life which significantly affected families as well. Sociological studies have discovered behavioral norms behind relationships in families and marriages being washed out, transformation in family roles, development of new norms and principles which come as a basis for matrimonial, parent-child and intergenerational relationships. The modern society experienced a critical shift in gender roles or parents. The role of a father and a male is losing its value. Some of the reasons are that in case of divorce in Russia children most usually stay with mothers.

Russian parents inherit family practices from their own parents and modify them in accordance with their own experience and feeling what would be most beneficial for their children. Parenting styles in Russia are based on Russian mentality, way of life, traditions and current environmental situation and thus may differ from the parenting patters of other countries. To analyze transformations in parenthood and parenting in a modern Russian family the paper refers to a study "Parenthood, upbringing and childhood in a modern Russian family" (Novgorod, 2013).
\end{abstract}

Keywords: family, marriage, matrimony, parenthood, parenting

\section{Introduction}

Sociologists often point to significant transformations in the domains of family and marriage. One of the most recent changes observed is a growing crack between three key components which until now have made up the core of family relationships: nuptiality, sexuality and procreation (Golod, 2008; Fine \& Fincham, 2013; Peterson $\&$ Bush, 2012). Minimum two relatively independent family areas have originated from this disconnection matrimony and parenthood which causes further separation between marriage and family.

Parenthood and parenting have always made a fascinating topic for researchers from everywhere in the world. Conceptual approaches to contemporary parenthood focus on its different aspects: spouses' reproductive expectations, styles in upbringing, sharing roles and responsibilities between family members (Gurko, 2008; Nieuwenhuis, 2014). A "New household" concept has introduced two restrictions into it: family budget and the time shared in a family. This sets up a new context where having children or not is now seen through the value of their 'utility" either as human capital, or as an opportunity to meet parents' expectations, or as a tool to pay back the costs associated with upbringing as with any other acquisitions made into a family (Nauck, 2001; Saralieva, Balabanov, \& Nauck, 2009; Saralieva, Balabanov, \& Nauk, 2009; Chernova \& Shpakovskaja, 2013; Gurko, 2014).

\section{Materials and Methods}

A longitudinal study into intimate relationships and family dynamics ("Panel Analysis of Intimate Relationships and Family Dynamics" (PAIRFARM) study) since 2007) in Germany has focused on the following key issues: family dynamics and partnership stability; reproductive expectations and child-bearing; parenthood and upbringing; intergenerational relationships (Working Paper No. 17 Panel Analysis of Intimate Relationships and Family Dynamics (pairfam) - Conceptual Framework and Design, 2013).

Multiple surveys studied how family is transformed when a child is born into it - which means a transition from partnership to parenting. Mostly, researchers were encouraged to study spouses' gender roles in upbringing; sharing responsibilities in a family and parents' employments, parental expectations from starting and bringing 
up a child, in-family communication and collaboration (Parker \& Hunter, 2011; Gurko, 2011; Egorova \& Sizova, 2014).

Studies on upbringing styles and disciplining a child, particularly those which discuss punishment/violence towards children, are steadily growing in number (Parents' Perspectives on Parenting Styles and Disciplining Children, 2013; Saralieva, Egorova, \& Sud'in, 2013).

Modern trends in parenthood development in European countries attract Russian sociologists as they provide valuable data to analyze (Avralev \& Efimova, 2014). Overall, Russia follows worldwide trends which transform families, spouses' employments, their reproductive expectations.

To study modern parenthood and parenting in Russia the paper refers to a sociological survey "Upbringing, parenthood and childhood in a modern Russian family" which was released by the Department of general sociology and social work at Lobachevsky State University of Nizhni Novgorod in 2013 with a financial support from Russian ministry of education and science, federal program "Scientists and educators for innovative Russia". The Head of the project is Z. Saralieva.

\section{Results}

The survey studies respondents from three age cohorts aged 17-21, 23-30, 33-40 in equal proportions who stay at different stages of a family cycle: when a vision about future family relationships is shaped and decisions about individual family strategies are taken; when a family is planned and a decision to have children is taken; when a family is started and children are born. Total number of respondents is $621,45 \%$ - males, $55 \%$ - females. Respondents from all age groups were requested to fill in identical questionnaire which made it possible to monitor dynamics of scores and values across three age cohorts within one generation.

Parents of under age children were requested to fill in an additional questionnaire to understand how they see their children's upbringing. The number of respondents is 218 . The share of parents in a junior cohort is $33 \%$, senior $-67 \%$. $64 \%$ - females, $36 \%$ - males. $64,5 \%$ parents had one child only, $29,9 \%$ - two children, $5,4 \%$ three and more.

Data was processed with Statistical Package for the Social Sciences (SPSS). Factor analyses was applied to the questions which are related to upbringing process. Minimum percentage to explain general dispersion is $54 \%$, Measure of Sampling Adequacy (MSA) of Kaiser-Meyer-Olkin (KMO) in all cases is no lower than 0,735.

As the survey confirms, children still come as a significant value for all age cohorts. $85 \%$ of those questioned agree that having children is very important while only $5 \%$ do not recognize children as their key life goal. Meanwhile, professional achievements remain equally important both for males and females. The junior age group shows the highest scores in job-related positions. The percentage of respondents who do not see professional achievements as their key life goal is lower than the percentage of those who are not much child-focused (2,6\% vs. $5,7 \%)$.

Overall, senior age group has generally met their reproductive objectives, however, $14,5 \%$ of them were either slow or unable to become parents yet, while another $6 \%$ have already started families with many children (see Table 1). Most respondents in the junior age cohort do not have children. An average Russian family tends to have one child only, so a fall in birth rates which started in the late nineties still continues.

Table 1. Number of children, $\%$

\begin{tabular}{cccc}
\hline Number of children & Aged 17-21 & Aged 23-30 & Aged 33-40 \\
\hline No children & 99 & 64 & 15 \\
One & 1 & 32 & 47 \\
Two & - & 5 & 32 \\
Three and more & - & - & 6 \\
\hline
\end{tabular}

$64 \%$ of children are raised in first-marriage, intact and healthy families. Almost $20 \%$ of the respondents bring up their children in a single-parent environment. As Table 2 shows, the most common root cause behind a single-parent family is a divorce $(13,4 \%)$, a child shares a family environment with a single parent 6 less times, and with a widowed parent 11 less times. Every 11th surveyed brings up a child in a repeated marriage, every 10 th - in an unregistered one. Various family environments trigger variations in parenting types which will result in single, non-resident, non-biological, unmarried types. 
Table 2. Parents' marital status, \%

\begin{tabular}{ccccc}
\hline Marital status & Total & Aged 17-21 & Aged 23-30 & Aged 33-40 \\
\hline Single & 2 & - & 4 & 2 \\
Married & 64 & - & 70 & 61 \\
Repeated marriage & 9 & - & 5 & 11 \\
Cohabitation & 10 & 100 & 6 & 11 \\
Divorced or marriage terminated & 13 & - & 15 & 13 \\
Widowed & 2 & - & - & 2 \\
\hline
\end{tabular}

As unregistered marriages have been steadily increasing in number over recent years, a key issue here is to understand how a couple could benefit from such family environment in meeting their reproductive objectives. Cohabiting couples normally have fewer children. Most unregistered marriages do not have any children at all, while every third has one child only; every tenth has two, $2 \%$ have three and more (see Table 3 ). Most registered marriages have at least one child, while 5\% have many. Thus, a marriage is still recognized as the most acceptable and healthiest partnership to start and bring up children in.

Table 3. Real number of children in different family types, $\%$

\begin{tabular}{lllll}
\hline Number of children & No children & One & Two & Three and more \\
\hline Marriage (first or repeated) & $14^{*}$ & $54^{*}$ & $27^{*}$ & 5 \\
Cohabitation & $58^{*}$ & $28^{*}$ & $12^{*}$ & 2 \\
\hline
\end{tabular}

* Statistically significant difference with p-value $<0,001$

While reproductive behavior is mostly determined by a real number of children in a family, reproductive objectives and plans show themselves as ideal and desired numbers of children (see Table 4).

Table 4. Ideal and desired numbers of children in a family, $\%$

\begin{tabular}{|c|c|c|c|c|}
\hline Ideal number of children & Total & $\begin{array}{l}\text { Aged } \\
17-21\end{array}$ & $\begin{array}{l}\text { Aged } \\
23-30\end{array}$ & $\begin{array}{l}\text { Aged } \\
33-40\end{array}$ \\
\hline No children & 1 & 2 & 1 & 2 \\
\hline One & 12 & 13 & 9 & 12 \\
\hline Two & 56 & 56 & 58 & 54 \\
\hline Three and more & 31 & 29 & 32 & 32 \\
\hline Desired number of children & Total & $\begin{array}{l}\text { Aged } \\
17-21\end{array}$ & $\begin{array}{l}\text { Aged } \\
23-30\end{array}$ & $\begin{array}{l}\text { Aged } \\
33-40\end{array}$ \\
\hline No children & 1 & 2 & 1 & 1 \\
\hline One & 16 & 16 & 18 & 16 \\
\hline Two & 43 & 35 & 43 & 43 \\
\hline Three and more & 17 & 12 & 20 & 18 \\
\hline $\begin{array}{l}\text { Missing values, including I have not thought about it yet, I am } \\
\text { not sure. }\end{array}$ & 23 & 35 & 18 & 22 \\
\hline
\end{tabular}

\section{Discussion}

As most respondents confirmed an ideal family must have at least two children, while every third opted for more. $1 \%$ of those questioned is sure that a family can still be enough successful if it has no children. In their own families respondents tend to be less focused on having many children, only every sixth is ready to bring up three children, $43 \%$ - two children, while every sixth has agreed to have no more than one. The junior age group is seen as the least promising in terms of meeting their reproductive objectives: $33 \%$ of its respondents see their future families with two children, while only every tenth accepts a family with many children. This age group also showed the highest numbers of those respondents who have not made theirs decisions yet. 
Reasons which prevent respondents from starting any children/having more children vary; however, the most common of them is feeling "fear for their children's future" (38\%). People still remain uncertain of tomorrow and this feeling dramatically affects whether a decision to start a second/third child is taken or not (Chao, 1994). Financial hardships, low income (25\%), too much workload which is associated with a birth of a child (12,3\%) also force people to keep their reproductive needs under tight control. A child is also seen as a threat to respondents' career development plans (15\%).

Parents always associate child's birth with some particular expectations. All age cohorts named emotional motive (love, care, participation) as the main driving force which influenced their decision to have a child - 4,2 points (on a 5-point scale where 1 - "low value' and 5 is "high"). Parents also hope to receive adequate help and care from their grown-up children later in life and see them as caregivers who will support them in their senior years (Collins, 2000). To a lesser extent respondents expect a child's birth to make any dramatic changes in their social status or help them preserve youth for coming years (2.6 points). An approach developed by German researchers (Nauck, 2001) argue that children help parents meet three needs: comfort, respect/prestige and positive emotions (which reflect their «utility»); meanwhile they require financial resources and it determines costs of every child's birth (Darling \& Steinberg, 1993). If children are only seen as a source of positive emotions, having one, maximum two children can fully satisfy this demand. How many children is then enough to secure the highest status and respect for their parents? It largely depends on a particular social environment. If the utility-based approach prevails, then a family definitely need more children as profit grows with every new child who comes into a family. High costs associated with bringing up a child have a negative effect on desired numbers of children they would like to have. In Russia where emotional motivation is still strong enough, economic reasons also come into effect as severe financial hardships associated with a birth of every new child, most probably, may well neutralize all possible benefits, and make parents limit the number of children to the minimum.

A significant difference emerged when respondents from different age groups were asked to voice their fears related to children. The junior group demonstrates the highest scores here as they far more often think children can well limit their opportunities in key life domains (personal and professional) (Gonzales, Cause, \& Mason, 1996).

The key reasons behind a decision to give birth to a child include parents' financial security and wealth $(4,7)$, their psychological readiness for welcoming a child into a family $(4,6)$, which clearly demonstrates high responsibility among potential parents and their staying focused both on family planning and planned children.

Other important reasons given also include balancing partners' opinions on sharing responsibilities in a family and taking care of a child (3,9 points). Family environments where parents could happily combine upbringing and career development scored lowest ( 3,1 и 2,8 points respectively). Among all other age groups, the youngest parents appeared to be the most demanding in a situation when a child is born.

Following a birth of a child, respondents do not plan to significantly tailor their educational and professional ambitions as well as their attitudes to partners (2,7 and 2,3 points respectively). To be far more affected are leisure activities, hobbies (3,1 points), meeting friends (2,9 points). As parenthood and employment start to compete with each other, finding a healthy family-to-work balance in an uneasy social and economic environment comes as a new challenge for a family in Russia (Harris, 1998).

An insight into key characteristics of parent-child relationships has revealed that adults may feel uncomfortable and irresponsible as parents; they often treat a child as a source of discomfort and irritation and attribute their own faults in upbringing to him/her. We can identify three different approaches to children.

Table 5. Answers' average score to the question «How far are you prepared to limit yourself in these activities after the child's birth?»

\begin{tabular}{ccccc}
\hline Limitations & Total & Aged 17-21 & Aged 23-30 & Aged 33-40 \\
\hline Hobbies and interests & 3,1 & 2,8 & 3,1 & 3,1 \\
Socializing with friends, acquaintances or other people & 2,9 & 2,7 & 2,9 & 3,0 \\
Educational or professional goals & 2,7 & $2,3^{*}$ & $2,8^{*}$ & $2,9^{*}$ \\
Intimate relationships with a partner & 2,3 & 2,4 & 2,3 & 2,3 \\
\hline
\end{tabular}

The table shows the average score of judgements calculated on a 5-point scale where 1 - "not much" and 5 "very much". * marks significant difference at $\mathrm{p}<0,05$. 
The first position, "Parenthood/child is a source of excitement and positive emotions", is recognized as a norm. A caring parent benefits a lot from being involved into bringing up a child and socializing with him/her. The second, "Parenthood/child is a source of discomfort", is a negative position when parents feel trapped as they have to sacrifice most of their own time and ambitions for their child. Next is «The child is guilty" position and is applicable to the parents who do not feel full responsibility for bringing up a child; instead, they would rather make their own child feel guilty of various problems in upbringing they may experience.

Most parents questioned chose a child-centered (first) position (average value $-4,5$ ); however, a negative position also proved to be commonplace $(2,7)$, the least chosen is a "The child is guilty" position $(2,1)$.

Table 6. Self perception as a parent and perceiving a child

\begin{tabular}{cc}
\hline Judgements & Average score \\
\hline Parenthood/ child -source of excitement and positive emotions & 4,5 \\
Parenthood/ child - source of irritation & 2,7 \\
Child is guilty & 2,1 \\
\hline
\end{tabular}

To deal with a child parents accept both soft and hard parenting tools, the latter may include criticizing, humiliating and shouting at a child, termination of communication with him.

These tools can be found in six types of parents. Among them all only one meets the requirements for the right parenting style, others are referred to as wrong parenting styles/parents types. The first, "involved parenting", means allowing children to share their opinions with parents, providing unconditional support to them, a parent is fully engaged into what a child does. The second, "conflicting parenting", describes situations where children and parents have conflicting opinions, they often quarrel. The third one is accepting a child and encouraging his interests as much as parents can. Next is "strict parenting". The fifth type is "inconsistent parenting" where parents often change decisions and cancel punishments. The final one is "authoritarian parenting' which is characterized by a strict set of rules and expectations which a child must respect (Steinberg, 2001)?.

Only "conflicting parenting" shows a low average value $(2,4)$ which means it is least presented in child-parent interactions. Other parenting styles can be deduced from the opinions of the questioned parents.

Table 7. Style /type of parental communication

\begin{tabular}{cc}
\hline Judgements & Average score \\
\hline 1.Involved parent & 4,0 \\
2.Conflicting parent & 2,4 \\
3.Child-centered parent & 4,0 \\
4.Strict parent & 3,1 \\
5.Inconsistent parent & 2,8 \\
6.Tough/authoritarian parent & 2,8 \\
\hline
\end{tabular}

Parenting styles can be partially affected by social-demographic factors (education, gender, age). For example, having a university degree and its effect on parenting is debated. Parents with degrees tend to treat their children rather as a source of irritation/discomfort and this makes them often choose a strict and authoritarian parenting style. Unlike males, female parents are more likely to use «Parenthood/child is a source of irritation/discomfort» position. Meanwhile, male parents choose soft parenting tools less often; instead they prefer to shout at children and humiliate them; they are less involved in child's life and, as a result, they seldom conflict with them. Significant differences can be observed when parents from different age groups are compared. Parents from a junior age group treat a child rather as a source of positive emotions than irritation, they use hard parenting tools less often than their more senior counterparts. As senior parents are less concentrated on children, they seldom behave as authoritarian parents towards them.

\section{Conclusion}

Transformations in a modern family affect all subsystems of family interaction including parenthood. A married family is still recognized as optimal, most acceptable and healthiest environment to start and bring up children in, however, considering a variety of family environments children are often raised in single-parent, unregistered and repeated marriages. 
Russian family still chooses one-child family type. A study into reproductive expectations in different age groups as well as positive and negative motivations behind starting a child proved that a fall in birth rates is likely to continue. Like in most developed countries, in Russia parents see their child as someone who they love and care which explains low birth rates. Financial hardships which most families have to face now and a growing competition between family life and professional development makes the situation ever more painful.

Being a key feature of parenthood variability affects parenting styles in a modern family. Parents treat parental roles differently; they practice various parenting styles and methods and often make mistakes by choosing wrong ones.

\section{Acknowledgments}

1. Authors' team in longitudinal survey of family in Germany (2008-launched German Family Panel pairfam ("Panel Analysis of Intimate Relationships and Family Dynamics") and especially to Professor Bernard Nauck (University of Chemnitz, Germany).

2. Performers' team in «Upbringing, parenting and childhood in a modern Russian family” project.

\section{References}

Avralev, N., \& Efimova, I. (2014). Global university rankings as indicators of the implementation of the integration process and competitive tool in the context of globalization of higher education. Life Sci J., 11(10), 648-652.

Chao, R. (1994). Beyond Parental Control and Authoritarian Parenting Style: Understanding Chinese Parenting through the Cultural Notion of Training. Child Development, 65, 1111-1119. http://dx.doi.org/10.2307/ 1131308

Chernova, Zh. V., \& Shpakovskaja, L. L. (2013). Diskursivnye modeli sovremennogo roditel'stva. Zhenshhina v rossijskom obshhestve, 2(67), 14-26.

Collins, W. A. (2000). Contemporary Research on Parenting: The Case for Nature and Nurture. American Psychologist, 55, 218-232. http://dx.doi.org/10.1037/0003-066X.55.2.218

Darling, N., \& Steinberg, L. (1993). Parenting Style as Context: An Integrative Model. Psychological Bulletin, 113, 487-496. http://dx.doi.org/10.1037/0033-2909.113.3.487

Egorova, N. Ju., \& Sizova, I. L. (2014). Imeet li rossijskaja sem'ja shans stat' solidarnoj?. Sociologicheskie issledovanija, 4, 97-102.

Fine, M. A., \& Fincham F. D. (2013). Handbook of Family Theories: A Content-Based Approach (p. 512). Routledge.

Golod, S. I. (2008). Sociologo-demograficheskij analiz sostojanija i jevoljucii sem'i / Sociologicheskie issledovanija (№1. S. 40-49).

Gonzales, N., Cause, A. M., \& Mason, C. (1996). Interobserver Agreement in the Assessment of Parental Behavior and Parent-Adolescent Conflict: African American Mothers, Daughters, and Independent Observers. Child Development, 67, 1483-1498. http://dx.doi.org/10.2307/1131713

Gurko, T. A. (2008). Brak i roditel'stvo v Rossii (p. 325). M.: Institut sociologii RAN.

Gurko, T. A. (2011). Razvitie lichnosti podrostkov v razlichnyh tipah semej. Sociologicheskie issledovanija, 10, 99-108

Gurko, T. A. (2014). Reproduktivnye plany suprugov. Sociologicheskie issledovanija, 9, 77-85.

Harris, J. R. (1998). The Nurture Assumption: Why Children Turn Out the Way They Do. New York: Free Press.

Nauck, B. (2001). Value of children: Eine spezielle Handlungstheorie des generativen Verhaltens und von Generationenbeziehungen im interkulturellen Vergleich. Kolner Zeitschrift fur Soziologie und Sozialpsychologie, 53, 407-435. http://dx.doi.org/10.1007/s11577-001-0073-7

Nieuwenhuis, R. (2014). Family Policy Outcomes: Combining Institutional and Demographic Explanations of Women's Employment and Earnings Inequality in OECD countries, 1975-2005 Rense Nieuwenhuis (p. 276).

Parents' Perspectives on Parenting Styles and Disciplining Children. Retrieved May 21, 2013, from http://www.dcya.gov.ie/documents/publications/Parents_Perspectives_on_parenting_styles.pdf.

Parker, R., \& Hunter, C. (2011). Key factors affecting relationship satisfaction across the transition to 
parenthood № 20, AFRC Briefing. Retrieved May 21, 2013, from http://www.aifs.gov.au/afrc/pubs/briefing/ b020.

Peterson, G. W., \& Bush, K. R. (2012). Handbook of Marriage and the Family (p. 928). Springer Science \& Business Media.

Saralieva, Z. H., Balabanov, S. S., \& Nauk, B. (2009). Tipologija motivov imet' ili ne imet' detej. Sociologicheskie issledovanija, 3, 129-136.

Saralieva, Z. H., Egorova, N. Ju., \& Sud'in, S. A. (2013). Nasilie v shkole: pozicii shkoly i roditelej. Aktual'nye problemy roditel'stva v Rossii / Otv. red. T.A.Gurko. M.: Institut sociologii RAN, 2013. - C. 119-138.

Saralieva, Z., Balabanov, S., \& Nauck, B. (2009). Sozialer Tausch in den Verwandtschaftssystemen in Deutschland und Russland. Journal for Sociology of Education and Socialization, 1, 60-79.

Steinberg, L. (2001). We Know Some Things: Adolescent-Parent Relationships in Retrospect and Prospect. Journal of Research on Adolescence, 11, 1-20. http://dx.doi.org/10.1111/1532-7795.00001

Working Paper No. 17 Panel Analysis of Intimate Relationships and Family Dynamics (pairfam) - Conceptual Framework and Design. Retrieved May 21, 2013, from http://www.pairfam.de/en/publications/workingpapers.html

\section{Copyrights}

Copyright for this article is retained by the author(s), with first publication rights granted to the journal.

This is an open-access article distributed under the terms and conditions of the Creative Commons Attribution license (http://creativecommons.org/licenses/by/3.0/). 